\title{
Kualitas Hidup Pasien Pasca Bedah Pintas Arteri Koroner (BPAK)
}

\author{
Ida Rosidawati ${ }^{1}$, Kusman Ibrahim ${ }^{2}$, Aan Nuraeni ${ }^{2}$ \\ ${ }^{1}$ Universitas Muhammadiyah, Tasikmalaya, ${ }^{2}$ Fakultas Keperawatan, Universitas Padjadjaran \\ Email:Ida.rosidawati@umtas.ac.id
}

\begin{abstract}
Abstrak
Penyakit Jantung koroner (PJK) merupakan salah satu penyebab utama dan pertama angka kematian di negara maju dan berkembang, termasuk Indonesia. Angka kematian akibat PJK yang semakin meningkat perlu mendapatkan perhatian khusus. Upaya yang dapat dilakukan yaitu dengan tindakan Bedah Pintas Arteri Koroner (BPAK) yang dapat meningkatkan kualitas hidup pasien. Pasien pasca BPAK mengalami perubahan dalam hal bio-psiko-sosio-spiritual yang dapat memengaruhi kualitas hidup. Instrumen yang digunakan untuk mengukur kualitas hidup selama ini masih umum dan mengacu pada budaya dan pelayanan kesehatan di luar negeri, padahal kualitas hidup dipengaruhi oleh budaya setempat. Tujuan penelitian ini adalah untuk mengeksplor kualitas hidup pasien pasca BPAK di RSUP Dr. Hasan Sadikin Bandung. Metode penelitian yang digunakan adalah deskriptif kualitatif, dengan jumlah partisipan sebanyak 6 orang. Pengumpulan data dilakukan dengan cara wawancara semi terstruktur yang mengacu pada intrumen Short Form 36. Analisa data menggunakan content analysis. Hasil Penelitian yaitu secara fisik semua partisipan masih merasakan nyeri di bekas luka operasi seperti kesemutan dan baal, tetapi tidak sampai mengganggu aktivitas sehari-harinya. Secara emosional semua partisipan mengungkapkan rasa bahagia karena sudah terbebas dari penyakitnya, walaupun tidak sembuh secara total tetapi semua partisipan menerima keadaan dirinya. Secara Sosial semua partisipan mengungkapkan bahwa dukungan keluarga dan dukungan orang sekitar sangat dibutuhkan. Bentuk spiritualitas pada penelitian ini adalah partisipan merasa lebih dekat dengan Tuhan dan lebih mensyukuri keadaannya sekarang. Berdasarkan hasil penelitian terdapat aspek baru yang didapatkan dari hasil penelitian ini yaitu pentingnya spiritualitas dalam kualitas hidup partisipan. Hasil penelitian ini diharapkan menjadi bahan pertimbangan dalam proses asuhan keperawatan.
\end{abstract}

Kata kunci: Bedah Pintas Arteri Koroner, Kualitas Hidup, Short Form 36.

\section{Quality of Life among Patients with Post Coronary Artery Bypass Surgery}

\begin{abstract}
Coronary Artery Diseases (CAD) remains one of the major problems lead to a high mortality rate in many countries including Indonesia. Thus, treatment such as coronary artery bypass surgery is considered as a common treatment to reduce the fatal risks. However, post-surgical problems may arise which can diminish the patient's quality of life regardless cultural and contextual causal factors. This descriptive qualitative study aimed to explore the quality of life among patients undergone the coronary artery bypass surgery in Dr. Hasan Sadikin General Hospital Bandung. Data were collected using an individual semi-structured interview following the Short Form 36 instrument (SF-36) with six participants were recruited. Content analysis was employed to analysis the transcribed data. Findings revealed that all participants have experienced pain, numbness and tingling sensations particularly on the surgical sites without the presence of any daily activity living disturbances. They expressed more positive emotional feelings because of having freedom from their illness. The presence of strong social supports given by families and relatives has motivated the patients to face their recovery phase. In addition, participants expressed the need to have spiritual care which can help them to feel getting closer to the Lord and being more grateful for whatever situations they may have at the moment. Findings have further emphasised the importance of spirituality in the achievement of good quality of life among the participants. The result is expected to contribute to the improvement of best quality of post-operative nursing care plan.
\end{abstract}

Keywords: Coronary Arterial By-Passed Surgery, post-operative care, quality of life, spirituality. 
Ida Rosidawati : Kualitas Hidup Pasien Pasca Bedah Pintas Arteri Koroner

\section{Pendahuluan}

Penyakit Jantung koroner (PJK) saat ini merupakan salah satu penyebab utama dan pertama angka kematian di negara maju dan berkembang, termasuk Indonesia. Pada tahun 2010, secara global penyakit ini menjadi penyebab kematian pertama di negara berkembang, menggantikan kematian yang disebabkan oleh penyakit infeksi. Diperkirakan pada tahun 2020 nanti, PJK menjadi pembunuh pertama dan tersering yakni sebesar $36 \%$ dari seluruh angka kematian (Depkes, 2006). Angka kematian akibat PJK yang semakin meningkat perlu mendapatkan perhatian khusus. Upaya yang dapat dilakukan yaitu dengan tindakan Bedah Pintas Arteri Koroner (BPAK) yang dapat meningkatkan kualitas hidup pasien. BPAK yaitu salah satu pengobatan pada penyakit jantung koroner. BPAK adalah suatu teknik yang menggunakan pembuluh darah dari bagian tubuh lain untuk melakukan bypass arteri yang menghalangi pemasokan darah ke jantung. Tujuan dilakukannya BPAK yaitu untuk mengoptimalkan fungsi jantung, melindungi jaringan miokardium, dan memperbaiki kualitas hidup pasien (Stillwell, 2011)

Kualitas hidup merupakan konsep multidimensional yang meliputi fisik, emosional dan sosial seseorang terhadap keadaan kesehatannya, walaupun komponen kualitas hidup pada setiap orang sama tetapi kualitas hidup seseorang bersifat individual dipengaruhi oleh faktor pribadi, lingkungan dan interaksi sosial (Wahyuni, 2010). Pasien pasca BPAK mengalami perubahan dalam hal bio-psiko-sosio-spiritual yang dapat memengaruhi kualitas hidup. Instrumen yang digunakan untuk mengukur kualitas hidup selama ini masih umum dan mengacu pada budaya dan pelayanan kesehatan di luar negeri. Instrumen yang digunakan untuk mengukur kualitas hidup pada pasien dengan angina, infark miokard dan gagal jantung adalah kuesioner Short Form 36 (SF-36). Kuesioner SF-36 terdiri dari 36 pertanyaan mencakup delapan bidang (domain) yaitu kesehatan secara umum, fungsi fisik, keterbatasan peran karena kesehatan fisik, keterbatasan peran karena masalah emosional, energi, kesejahteraan emosi, fungsi sosial, rasa nyeri.
Berbagai penelitian yang telah dilakukan untuk mengetahui kualitas hidup pasien pasca BPAK, diantaranya Hasil penelitian Simchem (2001), menunjukkan hasil bahwa lingkungan sosial pasien mempengaruhi kualitas hidup pasien. Abdurachim, Kalim, dan Radi (2007), menemukan bahwa usia lebih muda mempunyai kualitas hidup yang lebih baik, terutama pada masalah fisik (fungsi fisik, peran fisik, peran emosi, dan ringkasan komponen fisik) dibandingkan dengan usia lebih tua. Pekerjaan juga mempengaruhi kualitas hidup seseorang, seseorang yang sudah pensiun/tidak bekerja, dan yang tidak dapat bekerja lagi mempunyai kualitas hidup yang buruk. Sejalan dengan hasil penelitian Myles, Paul, Jennifer, Helen, Robet, dan David (2001), menemukan bahwa pemulihan berkualitas rendah pada hari-hari pertama setelah operasi dapat mempengaruhi kualitas hidup pada 3 bulan pertama setelah operasi. Hal ini memungkinkan diperlukannya strategi dukungan awal yang lebih efektif ketika pasien masih mengalami perawatan di rumah sakit (konseling, bantuan rumah, pemberitahuan dokter setempat, dan rehabilitasi jantung).

Hasil penelitian ini diharapkan bisa memunculkan pandangan baru tentang kualitas hidup pasien pasca bedah pintas arteri koroner di Indonesia yang diperlukan oleh perawat dalam merawat pasien, karena kualitas hidup seseorang dipengaruhi oleh budaya setempat. Adapun tujuan dari penelitian ini adalah untuk mengeksplor kualitas hidup pasien pasca BPAK di RSUP Dr. Hasan Sadikin Bandung.

\section{Metode Penelitian}

Metode penelitian yang digunakan adalah deskriptif kualitatif. Penelitian dilakukan terhadap 6 partisipan yang dipilih dengan menggunakan purposive sampling. Adapun kriteria partisipan adalah pernah dirawat di ruang CICU RSHS Bandung, pasca BPAK setelah enam (6) bulan, mampu berkomunikasi dengan baik dan kooperatif, tidak memiliki riwayat penyakit diabetes mellitus. Pengumpulan data dilakukan oleh peneliti sendiri dengan menggunakan pedoman wawancara semi terstruktur yang mengacu pada intrumen Short Form 36 (aspek fisik, emosional, dan sosial) yang 
Ida Rosidawati : Kualitas Hidup Pasien Pasca Bedah Pintas Arteri Koroner

dikembangkan oleh peneliti menjadi sebuah pertanyaan terbuka, sedangkan untuk aspek spiritualitasnya membuat pertanyaan sendiri. Alat perekam suara menggunakan MP3, serta analisa data menggunakan content analysis yang direkomendasikan oleh Hancock (2002) dan Elo dan Kyngas, (2007)

Pengumpulan data dimulai setelah peneliti memperoleh persetujuan etik dari pihak berwenang, kemudian peneliti menemui kepala ruangan CICU untuk memperkenalkan diri dan meminta ijin untuk mengambil data terkait partisipan pasca BPAK. Penentuan partisipan sesuai dengan kriteria penelitian. Sebelum wawancara dimulai, peneliti menelepon terlebih dahulu partisipan untuk memperkenalkan diri, melakukan kontrak waktu dan menanyakan alamat lengkap.

Peneliti mendatangi rumah partisipan sesuai dengan kontrak waktu yang telah disepakati, kemudian memperkenalkan diri dan membina hubungan saling percaya kepada partisipan dan keluarganya serta menjelaskan maksud dan tujuan dari penelitian. Setelah partisipan memahami tujuan dari penelitian dan memahami hak-hak mereka sebagai partisipan kemudian menandatangani surat kesediaan berpartisipasi atau informed consent. Peneliti menciptakan suasana yang nyaman dengan duduk berhadapan, postur tubuh terbuka dan dengan nada bicara yang rendah. Selanjutnya peneliti menyiapkan catatan dan menghidupkan MP3 untuk merekam pembicaraan antara peneliti dengan partisipan. Peneliti meletakkan MP3 ditempat terbuka dengan jarak kurang dari $50 \mathrm{~cm}$ dari partisipan. Peneliti memulai wawancara dengan mengajukan beberapa pertanyaan yang telah ditentukan sesuai dengan rumusan masalah. Hasil wawancara direkam dengan menggunakan MP3. Saturasi data tercapai setelah peneliti mewawancarai 6 orang partisipan.

Instrumen utama dalam penelitian ini adalah peneliti sendiri. Peneliti sendiri yang bertindak langsung untuk melakukan wawancara sekaligus menulis hasil rekaman dari semua percakapan partisipan. Kemudian dianalisis dengan menggunakan content analysis yang direkomendasikan oleh Hancock (2002) dan Elo \& Kyngas, (2007). Content analysis merupakan sebuah prosedur untuk mengkategorikan data verbal atau perilaku dengan tujuan klasifikasi, membuat ringkasan dan perhitungan. Content analysis terdiri dari coding dan mengelompokkan data. Hal ini untuk mengidentifikasi transkrip data dan untuk memilah-milah pesan penting yang tersembunyi di setiap wawancara. Prosedur ini terdiri dari serangkaian langkah yaitu sebagai gambaran deskriptif mengenai data yakni apa yang sesungguhnya dikatakan tanpa interpretasi ke dalamnya dan tanpa asumsi. Tingkat analisis yang lebih tinggi adalah interpretatif, hal ini berkaitan dengan apa yang dimaksud dengan respon, apa yang terekam atau tersirat.

Peneliti dalam penelitian ini memperhatikan keabsahan data yaitu dengan cara peneliti mengumpulkan data secara rinci dan komprehensif, yang menggambarkan secara keseluruhan apa yang sedang terjadi. Dengan cara ini peneliti tidak hanya mengumpulkan data yang bersifat sepihak, yaitu hanya mendukung atau menolak dugaan atau interpretasinya saja.

\section{Hasil Penelitian}

Partisipan yang berpartisipasi pada penelitian ini sebanyak 6 orang. Jenis kelamin laki-laki sebanyak 5 orang, dan perempuan sebanyak 1 orang. Usia partisipan berkisar antara 53 tahun sampai dengan 65 tahun. Tingkat pendidikan bervariasi mulai dari Sekolah Menengah Pertama (SMP), Sekolah Menengah Atas (SMA), dan Sarjana. Pekerjaan partisipan diantaranya adalah wiraswata, pekerja Badan Usaha Milik Negara (BUMN), purnawirawan Tentara Negara Indonesia Angkatan Udara (TNI AU), pensiunan Pegawai Negeri Sipil (PNS), dan tidak bekerja. Seluruh partisipan beragama Islam. Berasal dari suku sunda dan sudah menikah. Memiliki rumah sendiri. Pendapatan per bulan mulai dari 1 juta sampai 8 juta. Sistem pembayaran pengobatan oleh Asuransi Kesehatan PNS, Jaminan Kesehatan Masyarakat (Jamkesmas), Badan Penyelenggara Jaminan Sosial (BPJS). Lamanya waktu menjalani hidup pasca bedah pintas arteri koroner sangat bervariasi mulai dari 6 bulan sampai dengan 1 tahun. Alamat partisipan yaitu Cimahi Selatan (dua orang), Cicaheum, Cibiru, Rancaekek dan Tasikmalaya. Adapun hasil penelitian ini 
Ida Rosidawati : Kualitas Hidup Pasien Pasca Bedah Pintas Arteri Koroner

terdiri dari 10 kategori, terdiri dari:

1. Fungsi fisik.

Setelah dilakukan tindakan BPAK, fungsi fisik kembali optimal, seperti berjalan kaki, mampu menaiki anak tangga, mengendarai kendaraan bermotor, bersepeda, angkat barbel, mandi/berpakaian sendiri. Berikut beberapa pernyataan dari partisipan :

"Saya bekerja di perusahaan pesawat terbang, jarak dari tempat parkir ke tempat kerja 800 meter. Setiap hari saya jalan kaki atau kadang pakai sepeda”. (P3).

"Naik tangga sudah kuat sekarang, tidak sesak napas lagi seperti dulu”. (P4)

"Bapak kan wiraswasta sering bepergian bawa motor, mobil. Bawa motor kurang lebih pulang operasi sebulan setengah". (P1)

"Setiap pagi saya bersepeda dengan jarak sekitar 2 kilometer”.(P6)

"Saya kan udah pensiun jadi sehari-hari ya kebanyakan olahraga, jalan kaki tiap pagi dan angkat barbel". (P5)

"Alhamdulillah sekarang mandi bisa sendiri, memakai baju juga sendiri tidak takut lagi lukanya membuka”. (P3)

2. Keterbatasan peran karena kesehatan fisik. Partisipan pada penelitian ini mengungkapkan dengan keterbatasan fisik dan usia yang sudah tua, tidak banyak aktifitas yang bisa dilakukan sehari-hari, hanya diam di rumah saja. Berikut pernyataan partisipan:

"Di rumah saja bapak mah neng, sudah tidak bekerja lagi”. (P2)

Menurut partisipan bekerja merupakan tugas dia sebagai karyawan, sehingga dengan keadaannya sekarang ini tetap dituntut untuk bekerja walaupun dengan keterbatasan. Berikut pernyataan partisipan:

"Saya sudah bisa kembali bekerja lagi ke kantor, tetapi hanya dengan tugas yang bisa dilakukan sambil duduk dan tidak terlalu berat”. (P3)

Beberapa partisipan mengungkapkan bahwa dengan keadaannya sekarang ini, sudah tidak bisa bekerja lagi sehingga masalah mencari nafkah diambil alih oleh anak dan istrinya. Berikut pernyataan partisipan:

"Bapak kan sudah tidak bekerja, jadi uang diberi sama anak saja”. (P6)

"Sekarang bapak sudah tidak bekerja lagi, yang mencari nafkah ibu saja neng, membuat kue kering”. (P2)

\section{Gaya hidup yang lebih baik.}

Gaya hidup yang lebih baik yaitu pembatasan makanan yang di konsumsi, rajin berolahraga, dan berhenti merokok. Berikut pernyataannya: "Makanan yang jelas yang lemak lemak, kolesterol tinggi dihindari. Dokter menyarankan bapak tidak boleh gemuk”. (P5)

"Jadi ketagihan olahraga, dulu itu ga pernah olahraga. Sekarang kalau berdebar-debar jalan-jalan saja di rumah, alhamdulillah hilang”. (P6)

"Kita harus komitmen menjaga kesehatan dengan cara mempertahan kan pola makan, pola tidur, pola olahraga, pola istirahat, harus sesuai”. (P5)

"Sekarang merokok sudah berhenti begitu diperiksa ke dokter terus didiagnosa terkena penyakit jantung langsung berhenti, itu pada tahun 2000”. (P1)

4. Vitalitas dan semangat hidup menjadi lebih baik.

Setelah dilakukan tindakan BPAK, partisipan mengungkapkan sepuluh tahun lebih muda dengan kondisinya sekarang ini. Berikut pernyataan partisipan:

"Saya merasa 10 tahun lebih muda baik kekuatan atau semangat”. (P5)

Partisipan mengungkapkan setelah dilakukan tindakan BPAK, seolah-olah memiliki tenaga yang maksimal sehingga partisipan ke dua ini tidak merasakan cape dan lelah. Berikut pernyataannya:

"Nah kalau jalan kaki itu cape kalau lambat, jalannya itu harus cepat. Kalau dulu sebelum operasi jalan tidak kuat, sesudah operasi mah jalan kaki sampai Cihampelas juga kuat (rumahnya di daerah Cikadut, Cicaheum)". (P2) 
Ida Rosidawati : Kualitas Hidup Pasien Pasca Bedah Pintas Arteri Koroner

5. Kesejahteraan emosional.

Perasaan bahagia muncul karena diberikan kesempatan kedua dalam kehidupannya. Berikut pernyataan partisipan:

"Alhamdulillah neng bapak merasa bahagia, diberi kesempatan kedua untuk hidup”. (P3)

Partisipan mengungkapkan setelah dilakukan operasi efek samping yang terjadi diterimanya dengan ikhlas, karena yang penting bisa sehat kembali. Berikut pernyataan partisipan:

"Ibu sudah ikhlas. Maksudnya juga ingin sehat, tetapi setelah operasi kaki malah lemes ....ah pasrah saja yang penting mah bisa sehat lagi”. (P4)

"Keluhan nyeri di luka bekas operasi itu tidak terlalu bermasalah, malah dengan keadaan sekarang saya bisa lebih enjoy”. (P5)

Perasaan bosan diungkapkan oleh dua partisipan, bosan karena tidak ada aktivitas yang bisa dilakukan karena sudah tidak bekerja lagi. Berikut pernyatan partisipan:

"Bosan neng...di rumah saja, bapak kan sudah tidak bekerja”. (P2)

6. Fungsi Sosial.

Kegiatan sosial dengan keluarga, tetangga dan teman berjalan seperti biasanya, bahkan partisipan mengungkapkan kebiasaannya dulu menjadi contoh yang tidak baik bagi temantemannya. Berikut pernyataan partisipan:

"Untuk teman-teman, saya itu menjadi contoh yang tidak baik apalagi buat yang merokok,... ini akibat dari merokok (sambil menunjuk ke luka bekas operasi)". (P6)

7. Nyeri dirasakan seperti kesemutan dan baal. Nyeri yang dirasakan oleh partisipan dalam penelitian ini adalah nyeri luka insisi seperti kesemutan dan baal, tetapi tidak mengganggu aktivitas sehari-harinya. Tindakan BPAK dilakukan dengan cara membelah tulang daerah dada, kemudian pembuluh darah vena diambil dari betis. Hal tersebut menimbulkan luka operasi yang panjang yang dapat menimbulkan ketidaknyamanan. Semua partisipan mengeluh hal yang sama. Berikut salah satu ungkapan partisipan:

“.....Nah ini bekas operasi masih terasa kesemutan karena pembuluh darahnya tidak ada, ini masih terasa baal (sambil menunjuk ke bekas luka operasi di daerah betis). Sedikit tidak terlalu bengkak, dulu bengkak.” (P1)

8. Kesehatan pulih kembali.

Kesehatan pulih kembali pada penelitian ini adalah terbebas dari penyakit keluhan, sehat optimal, aktivitas kembali normal. Berikut pernyataan beberapa partisipan:

"Alhamdulillah sesak napas nya hilang" (P4)

"Alhamdulillah bapak di operasi, sekarang sudah ada 9 bulan, ada kemajuan jauh banget ya kurang lebih 90\%”. (P1)

"Sesudah dua bulan operasi hubungan suami istri kembali normal, dulu ketika saya masih sakit cairan sperma nya encer gitu neng ". (P6).

9. Dukungan Sosial.

Dukungan Sosial dalam penelitian ini adalah dukungan keluarga, perubahan perhatian dari orang terdekat. Berikut pernyataan partisipan yang menyebutkan bahwa dukungan datang dari keluarga:

"Keluarga jelas memberi motivasi dan komitmen dalam menjaga kesehatan, dari olahraganya makanannya. jogging tiap pagi, olahraga dua hari sekali. ibu juga suka ikut". (P5)

Dukungan tidak hanya datang dari keluarga inti tetapi bisa juga datang dari saudara kandung. Berikut pernyataan partisipan yang menyebutkan bahwa dukungan datang dari kakaknya.

"Dukungan ti keluarga neng, bapak di operasi karena didukung oleh kakak bapak”. (P6)

Perhatian dari orang terdekat sangat bermanfaat bagi kesembuhan pasien, karena dapat menimbulkan bahwa pasien tersebut berarti dan diterima oleh orang lain. Berikut pernyataan partisipan.

"Rekan rekan sangat memperhatikan kondisi saya termasuk bos saya juga. Jangan terlalu cape termasuk saya harus tugas keluar negeri ga diizinin, tetangga semua baik memperhatikan saya." (P3)

10. Pentingnya Spiritualitas.

Spiritualitas dalam penelitian ini merupakan kategori tambahan yang ditemukan oleh 
Ida Rosidawati : Kualitas Hidup Pasien Pasca Bedah Pintas Arteri Koroner

peneliti karena dalam intrumen SF-36 hal tersebut belum tergali. Spiritualitas yang diungkapkan partisipan terdiri dari 2 sub kategori, yaitu rasa syukur dan lebih dekat dengan Allah.

Pelaksanaan ritual keagamaan menjadi meningkat setelah dilakukan operasi. Hal itu dilakukan sebagai upaya rasa bersyukur karena sudah diberi kehidupan yang kedua kalinya. Seperti yang diungkapkan berikut ini: "Ada peningkatan dalam beribadah yaitu bersyukur...sudah diberikan kehidupan yang kedua. Kalau mau sombong, dahulu sholat tahajud itu seminggu dua kali sekarang tiap malam, kalau tidak tahajud itu serasa saya punya hutang”. (P3)

Operasi BPAK membuat keluhan-keluhan yang sebelumnya dirasakan berkurang bahkan menghilang, sehingga dalam melakukan ritual ibadah partisipan akan lebih tenang dan khusyu. Berikut pernyataan partisipan:

"Alhamdulillah setelah operasi mengalami peningkatan dari sebelum operasi. Sebelum operasi untuk khusyu juga tidak bisa karena sakit. Setelah sekarang sembuh ya bisa melakukan dengan khusyu, membaca alquran, puasa sunah". (P5)

Sakit merupakan teguran atau cobaan yang diberikan oleh Allah SWT untuk meningkatkan derajat keimanan kita. Pernyataan dari partisipan,yaitu:

"Dengan bapak sehat lagi, bapak mendapat mukjizat, Allah memberikan kesempatan kedua. Sehingga saya tidak akan menyianyiakan kesempatan ini. Tadi sudah saya sebutkan saya merasa lebih dekat dengan Allah”. (P3)

\section{Pembahasan}

Kualitas hidup pasien pasca bedah pintas arteri koroner secara garis besar mengacu pada instrument SF 36 karena instrumen yang sering digunakan untuk mengukur kualitas hidup pada pasien dengan angina, infark miokard dan gagal jantung adalah kuesioner Short Form 36 (SF-36). Kuesioner SF-36 terdiri dari 8 bidang (domain) yaitu fungsi fisik, keterbatasan peran karena kesehatan fisik, keterbatasan peran karena masalah emosional, energi, kesejahteraan emosi, fungsi sosial, rasa nyeri, dan kesehatan secara umum. Hasil penelitian tentang uji validitas dan reliabilitas kuesioner SF 36 menunjukkan bahwa kuesioner SF-36 berbahasa Indonesia dengan penyusunan format baru Cronbach $\alpha=0.789$ (Salim, 2015) dan Cronbach $\alpha$ = 0.7 (Rachmawati, Perwitasari, \& Adnan, 2014) yang berarti memiliki reliabilitas dan repeatabilitas yang baik.

\section{Fungsi Fisik.}

Fungsi fisik yang dikaji dalam instrumen SF-36 meliputi kegiatan yang penuh semangat seperti berlari, mengangkat benda berat, berpartisipasi dalam olahraga berat, kegiatan sedang seperti memindahkan meja, mendorong vacuum cleaner, bermain golf/ bowling, mengangkat/ membawa belanjaan, menaiki anak tangga, membungkuk/berlutut, berjalan kaki, mandi/memakai baju sendiri. Fungsi fisik tambahan yang ditemukan pada penelitian ini adalah bersepeda, mengendarai kendaraan bermotor, angkat barbel.

Partisipan dalam melakukan fungsi fisiknya yang berkaitan dengan kualitas hidup dipengaruhi oleh usia, seperti usia lebih muda mempunyai kualitas hidup yang lebih baik, terutama pada masalah fisik (fungsi fisik, peran fisik, peran emosi, dan ringkasan komponen fisik). Sejalan dengan penelitian Moons et al., (2004) mengatakan bahwa usia adalah salah satu faktor yang memengaruhi kualitas hidup. Penelitian yang dilakukan oleh Wagner, Abbot dan Lett (2004), menemukan adanya perbedaan yang terkait dengan usia dalam aspek-aspek kehidupan yang penting bagi individu. Berdasarkan penelitian yang dilakukan oleh Ryff dan Singer (dalam Papalia et al., 2007), menemukan bahwa individu dewasa mengekspresikan kesejahteraan yang lebih tinggi pada usia dewasa madya. Dilihat dari usia masing -masing partisipan mulai dari usia 53 tahun sampai 65 tahun, usia tersebut tergolong ke dalam usia lanjut. Perawatan yang dilakukan harus sabar, teliti dan penuh cinta sehingga dapat meningkatkan kualitas hidup.

2. Keterbatasan peran karena kesehatan fisik. Keterbatasan peran karena kesehatan fisik yang dikaji dalam instrumen SF-36 meliputi kegiatan sehari-hari yang dilakukan terbatas, 
Ida Rosidawati : Kualitas Hidup Pasien Pasca Bedah Pintas Arteri Koroner

membutuhkan tenaga ekstra, sedangkan partisipan dalam penelitian inimengungkapkan bahwa keterbatasan peran karena kesehatan fisik yaitu aktivitas di rumah saja, kembali bekerja tetapi dengan keterbatasan, serta peran sebagai pencari nafkah mengalami perubahan.

Beberapa partisipan mengungkapkan bahwa setelah operasi walaupun sudah kembali sehat tetapi kalau untuk bekerja lagi tidak memungkinkan. Salah satunya faktor usia yang sudah lanjut dan keterbatasan fisik. Sehingga untuk peran mencari nafkah digantikan oleh istri dan anaknya. Partisipan merasakan penurunan kualitas hidupnya karena tidak bisa melaksanakan perannya dengan baik. Perubahan peran pada penelitian ini yang dimaksud oleh partisipan adalah setelah operasi tidak bisa bisa mencari nafkah kembali, sehingga istri dan anaknya yang sekarang mencari nafkah. Berbeda dengan beberapa partisipan lain yang menyatakan kualitas hidupnya menjadi lebih baik, karena bisa kembali bekerja lagi, sejalan dengan penelitian Leeanna (2005), bahwa partisipan dengan pasca BPAK mempunyai kekuatan untuk sembuh karena aktifitas yang bisa dilakukannya setelah dilakukan operasi seperti kembali bekerja atau melakukan hobi yang dimilikinya.

\section{Keterbatasan peran karena masalah} emosional.

Partisipan mengungkapkan bahwa ada perasaan takut untuk terjadi serangan ulang. Hal tersebut diantisipasi dengan melakukan perubahan gaya hidup ke arah yang lebih baik. Beberapa partisipan mengungkapkan bahwa setelah dilakukan tindakan BPAK, gaya hidup mereka berubah. Pada awalnya tidak sama sekali melakukan olahraga sekarang menjadi ketagihan berolahraga setiap harinya. Partisipan lain juga mengungkapkan sekarang bisa berhenti secara total untuk tidak merokok, makanan pun dijaga dengan ketat. Hal tersebut dilakukan guna menjaga kesehatan jantungnya. Makanan sehat juga dapat memengaruhi hasil dari operasi termasuk status fisik, status mental, dan semua aspek kualitas hidup. Pasien pasca BPAK yang makan lebih banyak buah-buahan mempunyai kualitas hidup yang lebih baik dibandingkan dengan makan goreng-gorengan (Tung et al. 2011).
Fokus perawatan pasca BPAK pada minggu pertama adalah masalah fisik dan emosi, dengan melakukan deteksi dini dan pencegahan komplikasi yang mengancam nyawa. Menjelang akhir bulan pertama setelah keluar dari rumah sakit berfokus pada membangun toleransi untuk aktifitas seharihari. Selama pemulihan pada bulan kedua dan ketiga berfokus pada kegiatan kerja dan kembalinya aktivitas seksual dan sosial. Selama bulan keempat sampai bulan keenam, tujuan pemulihannya untuk mencapai tingkat aktivitas maksimal dan perubahan gaya hidup program jangka panjang seperti program latihan, diet dan manajemen (Gonce et al. 2013).

4. Vitalitas dan semangat hidup menjadi lebih baik.

Salah satu faktor yang mempengaruhi kualitas hidup seseorang pada penelitian ini yaitu adanya semangat hidup yang tinggi. Hal ini diungkapkan oleh dua partisipan. Semangat hidup yang tinggi bisa muncul dari spiritualitas klien. Klien percaya kesehatannya sekarang karena kasih sayang dari Allah. Sebagaimana penelitian yang dilakukan spirit yang positif adalah kunci kesuksesan dalam proses penyembuhan, kesembuhan yang didapat karena tuhan melihat dan mengabulkan doadoanya (Leeanna, 2005).

\section{Kesejahteraan emosional.}

Hampir seluruh partisipan mengungkapkan bahagia karena bisa sehat kembali dan berkumpul dengan keluarga. Hal tersebut berbeda dengan partisipan satu yang mengungkapkan bahwa setelah dilakukan operasi, perasaan menjadi mudah tersinggung. Hal tersebut didukung oleh Karlsson (2000) dalam penelitiannya mempelajari hubungan antara kualitas hidup dengan keadaan emosional. Keadaan emosional merupakan tolak ukur secara tidak langsung dari kualitas hidup dalam kaitannya dengan operasi BPAK. Perasaan bosan diungkapkan oleh dua partisipan, hal tersebut karena tidak adanya aktivitas yang dikerjakan setiap harinya. Semenjak didiagnosis penyakit jantung langsung berhenti bekerja. Sekarang setelah di operasi, partisipan mengalami keterbatasan dalam melakukan aktivitas, sehingga untuk kembali bekerja sudah tidak memungkinkan 
Ida Rosidawati : Kualitas Hidup Pasien Pasca Bedah Pintas Arteri Koroner

lagi. Selain masalah itu, dilihat dari segi usia sudah masuk kategori lansia, dimana perusahaan tidak mungkin merekrut karyawan seumurannya.

Beberapa partisipan menyatakan bahwa apapun yang terjadi baik sebelum maupun sesudah dilakukan tindakan BPAK mereka pasrah, siap menerima keadaan dirinya. Pernyataan partisipan tentang kepasrahan tersebut tidak terlepas dari nilai-nilai yang ada dalam ajaran Islam. Partisipan mengungkapkan telah pasrah karena yakin akan adanya pertolongan Allah, karena dalam ajaran Islam satu-satunya penolong bagi setiap manusia adalah Allah SWT. Penelitian kualitatif yang dilakukan oleh Leeanna (2005), beberapa partisipan mengungkapkan bahwa mereka menerima hasil setelah dilakukan operasi walaupun hal tersebut dirasakan kurang memuaskan seperti adanya luka insisi, adanya penimbunan cairan didalam paru-paru.

\section{Fungsi sosial.}

Fungsi sosial yang diungkapkan oleh partisipan dalam penelitian ini adalah menjadi contoh yang tidak baik bagi teman-teman partisipan. Efek dari merokok salah satunya yang bisa mengakibatkan terjadinya penyakit jantung koroner. Akumulasi plak dapat dipercepat oleh rokok, tekanan darah tinggi, kolesterol yang meningkat, dan diabetes. Pasien juga berisiko tinggi terbentuk plak jika mereka berusia lanjut (lebih dari 45 tahun untuk lakilaki dan 55 tahun untuk perempuan) atau jika mereka memiliki riwayat keluarga positif untuk penyakit arteri koroner (Setianto, 2009; David, 2005; Santoso \& Setiawan, 2005).

7. Nyeri dirasakan seperti kesemutan dan baal. Pembuluh standar yang dipakai dalam melakukan BPAK adalah vena safena magna tungkai dan arteria mamaria interna kiri (Left Internal Mammaria Artery, LIMA) dari dada, berdasarkan hasil observasi ketika wawancara pembuluh darah yang digunakan untuk tindakan BPAK semua partisipan diambil dari vena safena magna tungkai. Semua partisipan yang diwawancara menyatakan bahwa mereka merasakan nyeri di bekas luka operasi baik itu yang di kaki maupun yang di dada. Nyeri yang dirasakan sebenarnya tidak terlalu mengganggu aktifitas hanya dirasakan tidak nyaman.
Sebagaimana penelitian yang dilakukan Kan (2007) yang menemukan bahwa dalam enam bulan pertama setelah operasi, 81 dari 82 pasien melaporkan berbagai masalah meliputi masalah kondisi fisik (kelelahan, penurunan mobilitas, nyeri insisi, ketidaknyamanan).

8. Kesehatan pulih kembali.

Kesehatan umum yang dikaji dalam instrumen SF-36 meliputi persepsi tentang kesehatan, lebih mudah sakit, sehat, kesehatan memburuk dan kesehatan sangat baik, sedangkan kesehatan secara umum yang persepsikan oleh partisipan dalam penelitian ini yaitu terbebas dari penyakit/ keluhan, sehat optimal dan aktivitas seksual kembali normal.

Seluruh partisipan yang diwawancara menyatakan bahwa kesehatan secara umum bagi mereka adalah merasakan bebas dari penyakit atau keluhan. Keluhan-keluhan yang dirasakan sangat mengganggu pada saat sebelum operasi, setelah operasi keluhan tersebut berkurang bahkan hilang dengan dilakukannya operasi BPAK.

Partisipan lain juga mengungkapkan bahwa kesehatan itu menurut mereka adalah sehat optimal. Sejalan dengan penelitian kualitatif yang dilakukan di Thailand oleh Kan (2007), bahwa setelah dilakukan operasi BPAK partisipan mengungkapkan kembali normal lagi. Partisipan tiga juga mengungkapkan setelah dilakukan tindakan BPAK, merasa seperti bayi baru lahir dan memiliki jantung baru lagi. Didukung oleh Leeanna (2005), dalam penelitian kualitatifnya bahwa setelah dilakukan operasi BPAK partisipan kembali hidup sehat lagi dengan tetap memperhatikan beberapa hal seperti pembatasan makanan, mulai latihan olahraga, kontrol emosi.

\section{Dukungan Sosial.}

Klien pasca BPAK merupakan individu yang rentan, yakni orang-orang yang mempunyai kecenderungan beresiko dalam perkembangan kesehatannya, yang mempunyai keterbatasan dalam akses ke pelayanan kesehatan atau orang yang tergantung pada orang lain dalam perawatannya (Potter \& Perry, 2005). Klien pasca BPAK dalam hal ini memerlukan perawatan khusus akibat keterbatasan fisik yang dideritanya karena jantung sebagai organ utama yang berfungsi memompa darah dan mengalirkannya ke seluruh tubuh mengalami 
Ida Rosidawati : Kualitas Hidup Pasien Pasca Bedah Pintas Arteri Koroner

perubahan sehingga diharapkan dapat beradaptasi dengan kondisi klien. Disamping itu klien pasca BPAK akan selamanya harus beradaptasi dengan kondisi jantungnya saat ini. Hal ini tentunya akan berpengaruh terhadap gaya hidup, aktifitas dan hubungan dengan orang lain. Hal tersebut akan berpengaruh dengan kualitas hidup klien.

Beberapapartisipanmengungkapkan bahwa keluarga sangat dibutuhkan dalam melakukan berbagai aktifitasnya, dalam menjaga kesehatan, dalam menyiapkan makanan, menjaga emosinya, sehingga keluarga harus benar-benar berkomitmen dalam menjaga kesehatan bagi seluruh anggotanya. Dari hasil penelitian ini didapatkan bahwa dukungan dari keluarga merupakan salah satu faktor yang mempengaruhi kualitas hidup seseorang. Hal ini diungkapkan oleh dua partisipan. Dukungan dari keluarga dalam penelitian ini dipersepsikan oleh partisipan dengan perhatian dan kehadiran dari keluarga yang selalu mendampingi.

Hal ini sesuai dengan teori bahwa pasien adalah makhluk sosial yang membutuhkan orang lain untuk menjalani kehidupannya. Klien pasca BPAK adalah makhluk sosial yang membutuhkan dukungan sosial. Ada empat kategori salah satunya adalah dukungan sosial yaitu dukungan emosional, yang umumnya berasal dari keluarga meliputi perhatian, kepedulian, mencintai dan kepercayaan. Kehadiran keluarga yang selalu mendampingi klien akan meningkatkan motivasi klien untuk dapat beradaptasi dengan kondisinya, disamping itu keluarga juga dapat memberikan instrumental support dengan membantu pembiayaan perawatan yang dibutuhkan klien. Anggota keluarga merupakan orang terdekat pasien yang dapat memberikan dukungan baik fisik, psikologis maupun spiritual. Dalam penelitian ini sebagian besar partisipan mendapatkan dukungan dari pasangan, anak dan orang tua. Partisipan mengungkapkan semakin bersemangat untuk sembuh karena ingin melihat anaknya sukses dan bahagia. Jika dipandang dari sisi budaya, dukungan sosial yang didapatkan oleh partisipan salah satunya adalah kehadiran keluarga merupakan hal yang umum terjadi dalam budaya asia termasuk Indonesia. Dalam adat ketimuran dirasakan bahwa hubungan sosial merupakan hal yang sangat penting.
Pernyataan ini didukung oleh Friedman, Bowden \& Jones (2003), menyatakan bahwa baik individu maupun keluarga di negara timur, termasuk Indonesia, memiliki nilainilai tradisional antara lain: familism, keluarga sebagai sentral, saling ketergantungan, mempertahankan keharmonisan. Selain dari dukungan keluarga inti, dukungan dari kerabat, rekan kerja itu sangat penting dalam kualitas hidup partisipan. Partisipan tiga mengungkapkan bahwa rekan kerjanya termasuk bos nya sangat memperhatikan dirinya, beigutupun dengan partisipan enam mengungkapkan bahwa dukungan dari saudara kandung dirasakan sangat berarti, dimana bantuan materil sangat diperlukan ketika dalam keadaan tidak berdaya.

10. Pentingnya Spiritualitas.

Spiritual sering didefinisikan sebagai kesadaran dalam diri seseorang dan rasa terhubung dengan sesuatau yang lebih tinggi, alami, atau kepada beberapa tujuan yang lebih besar dari diri sendiri. Bila dikaitkan dengan konteks Islam, tidak ada spiritualitas tanpa keyakinan, ajaran, dan amal agama. Agama merupakan sistem hidup yang memberikan jalan spiritual untuk keselamatan dunia dan akhirat, seorang muslim tidak mungkin mencapai derajat spiritual yang tinggi tanpa menjalankan agamanya secara benar. Bentuk spiritualitas dalam penelitian ini adalah adanya dukungan dari keluarga, perubahan perhatian dari orang terdekat, rasa syukur dan lebih dekat dengan Allah.

Spiritual dalam konteks budaya barat berbeda dengan di Indonesia, karena negara barat adalah negara sekuler yang memisahkan antara masalah agama dengan masalah kehidupan. Spiritualitas adalah bersyukur karena telah mendapatkan karunia, yakni sehat kembali (Chao, Chen \& Yen, 2002).Nilai-nilai mengenai rasa syukur diajarkan dalam agama, menurut ajaran Islam disebutkan bahwa hidup akan menjadi bahagia bila menjadi manusia yang bersyukur, karena syukur mengajarkan kita untuk selalu memaknai setiap peristiwa kehidupan dari sudut pandang positif, karena itulah bersyukur akan membuat hati kita senantiasa tentram dan damai. Bentuk rasa syukur dalam penelitian ini adalah lebih rajin beribadah, membaca Al-Quran, berdoa dan sholat tahajud tiap malam. 
Ida Rosidawati : Kualitas Hidup Pasien Pasca Bedah Pintas Arteri Koroner

Semua partisipan beragama Islam sehingga nilai-nilai agama Islam kental mempengaruhi persepsi partisipan terhadap sakit yang dialami. Menurut ajaran Islam semua keburukan atau kemalangan maupun kebaikan atau keberuntungan merupakan cobaan atau teguran bagi manusia. Hal tersebut terdapat dalam Al Quran surat Al Anbiya ayat 35 yaitu cobaan ini diciptakan untuk menguji keimanan seseorang. Nilai-nilai inilah yang kemudian merubah persepsi partisipan dari memandang sakit sebagai penderitaan menjadi bentuk kasih sayang Tuhan melalui teguran maupun cobaan (Nuraeni et al., 2012). Dilihat dari sisi budaya, hampir semua partisipan berlatar belakang budaya sunda. Masyarakat sunda dikenal sebagai masyarakat religius, sehingga kebudayaannya pun banyak dipengaruhi oleh budaya Islam, sehingga akan sulit untuk memisahkan mana adat kebiasaan dan mana agama karena biasanya kedua hal tersebut terjalin erat menjadi kebudayaan orang sunda (Suryaman, 2011).

\section{Simpulan}

Berdasarkan hasil analisa data dan pembahasan, dapat disimpulkan bahwa kualitas hidup pada pasien pasca Bedah Pintas Arteri Koroner (BPAK) di RSUP dr Hasan Sadikin Bandung lebih baik sebelum dilakukan operasi. Dukungan keluarga dan teman dekat sangat berpengaruh terhadap kualitas hidup partisipan. Semua partisipan beragama Islam sehingga nilai-nilai agama Islam kental memengaruhi persepsi partisipan terhadap sakit yang dialami dan kualitas hidupnya, sehingga spiritualitas sangat berperan penting dalam meningkatkan kualitas hidup pasien pasca BPAK. Bentuk spiritualitas yang ditemukan pada penelitian ini adalah rasa syukur dan lebih dekat dengan Tuhan.

Hasil penelitian ini diharapkan dapat menjadi bahan pertimbangan dalam menentukan intervensi selanjutnya dalam asuhan keperawatan, karena dari hasil penelitian ini ditemukan aspek pentingnya spiritualitas dalam kualitas hidup partisipan, yang tidak terdapat pada instrumen SF 36. Hal tersebut karena masyarakat Indonesia merupakan masyarakat yang religius. Oleh karena itu, perlu kajian lebih lanjut untuk membuat instrumen kualitas hidup yang sesuai dengan latar belakang budaya Indonesia, karena kualitas hidup seseorang dipengaruhi oleh budaya dimana ia berada.

\section{DaftarPustaka}

Abdurachim, K., Kalim, H., Radi, B.(2007). Penilaian Kualitas Hidup Pasien Pasca Bedah Pintas Koroner yang Menjalani Rehabilitasi Fase III. Jurnal Kardiologi Indonesia. 28, 189-196.

Chao, C.S., Chen, C.H., \& Yen, M. (2002). The Essence of Spirituality of Terminally Ill Patient. Journal of Nursing Research, 10 (4), 237-245.

David, E.N (2005). Acute Coronary Syndrome. London: Elsevier.

Depkes RI. (2006). Profil Kesehatan Indonesia. Jakarta.

Elo, S., \& Kyngas, H. (2007). The Qualitative Content Analysis Process. Journal Compilation. 107-115.

Friedman, M., Bowden, V.R., \& Jones, E. (2003). Family Nursing: Research, Theory and Practice.5th ed. Stamford, CT: Appleton \& Lange.

Gonce, P., Morton, F., Hudak., \& Gallo. (2013).Keperawatan Kritis Pendekatan Asuhan Holistik. Jakarta: EGC.

Hancock, B. (2002). Trend Focus For Research and Development in Primary Health Care an Introduction to Qualitative Research. University of Notingham: Trent Focus Group.

Kan, E.Z.(2007). Adaptive Behaviors and Perceptions of Recovery Following Coronary Artery Bypass Graft Surgery. Disertasi.

Karlsson, I., Berglin, E., \& Larsson, P. (2000). Sense of Coherence : Quality of Life Before and After Coronary Artery Bypass Surgery A Longitudinal Study. Journal of advanced 
Ida Rosidawati : Kualitas Hidup Pasien Pasca Bedah Pintas Arteri Koroner

nursing. 31.

Leeannna, E.E. (2005). The Quality of Life in Older People After Coronary Artery Bypass Surgery. Disertasi.

Moons, P., Marquet, K., Budst, W., \& De Geest, S. (2004). Validity, Realibility and Responsiveness of the "Schedule for The Evaluation of Individual Quality of Life Direct Weighting" in Congenital heart disease. BioMed Central.

Myles., Paul., Jennifer, H., Helen, F., Robert, S., David, W. (2001). Relation Between Quality of Recovery in Hospital and Quality of Life 3 Month after Cardiac Surgery. Journal Anesthesiology.

Nuraeni, A et al. (2012). Eksplorasi Makna Spiritualitas pada Klien dengan Sindrom Koroner Akut yang Menjalani Perawatan di Ruang Rawat Intensif Khusus Jantung RSUP dr Hasan Sadikin Bandung. Tesis. Tidak Dipublikasikan.

Papalia, D., Sterns, H., Feldman, R.D., \& Camp, C. (2007). Adult Development and Aging. USA : McGraw-Hill Humanities.

Potter, P.A \& Perry, A.G. (2005). Fundamental of Nursing Concept, Process and Practice, New York : St. LouisMosby.

Rachmawati, Y., Perwitasari, D.A., \& Adnan. (2014). Validasi Kuesioner SF 36 Versi Indonesia Terhadap Pasien Hipertensi Di Puskesmas Yogyakarta. Pharmacy. Vol 11.

Salim. (2015). Validitas dan Reliabilitas Kuesioner Kualitas Hidup SF-36 dan Aquarel Berbahasa Indonesia pada Pasien dengan Pacu Jantung Permanen $=$ Validity and Reliability of Quality of Life SF-36 and Aquarel questionnaire in Bahasa on Patients with Permanent Pacemaker.

Santoso, M \& Setiawan, T. (2005). Penyakit Jantung Koroner. Cermin Dunia Kedokteran.

Stillwell S. (2011). Pedoman Keperawatan Kritis. Jakarta: EGC.

Setianto, B. (2009). Kejadian Kardiovaskuler Mayor Pada Perempuan. Jurnal Kardiologi Indonesia. 30: 13-14.

Simchem. (2001). Socio Demographic and Clinical Factors Associated with Low Quality of Life One Years after Coronary Bypass Operations. Journal of thoracic and cardiovascular surgery. The American association for thoracic surgery.

Suryaman, B. (2011). Budaya dan Kebudayaan Sunda.

Tung, H.H., Tseng, L.H., Wei, J., Lin, C.H., Wang, T.J.,\& Liang, S.Y. (2011). Food Pattern and Quality of Life in Metabolic Syndrome Patients Who Underwent Coronary Artery Bypass Grafting in Taiwan. European Journal of Cardiovascular Nursing. 10, 205.

Wagner, J.A., Abbot, G., \& Lett, S. (2004). Age Related Differences in Individual Quality of Life Domains in Youth with Type 1 Diabetes. BioMed Central.2: 54.

Wahyuni. (2010). Pengalaman Klien tentang Perawatan Post CABG terhadap Kualitas Hidup dalam Konteks Asuhan Keperawatan : Study Fenomenologi di UnitPelayanan Jantung Terpadu RSUPN dr Cipto Mangunkusumo Jakarta. Jurnal Universitas Indonesia. 